\title{
HAKEKAT PELAYANAN PUBLIK
}

\author{
Abu Bakar
}

Balai Diklat Keagamaan Palembang, Kementerian Agama

bakar.rwsu@gmail.com

\begin{abstract}
Abstrak
Esensi dari pelayanan publik ini menurut Denhardt, adalah sebagai berikut: melayani warga masyarakat bukan pelanggan, mengutamakan kepentingan publik, lebih menghargai warga negara ketimbang wirausahawan, berfikir strategis dan bertindak demokratis, menyadari bahwa akuntabilitas bukan merupakan yang mudah, melayani daripada mengendalikan, menghargai orang, bukan produktivitas semata, melalui pelayanan barang publik; pelayanan jasa publik, dan pelayanan adminsitratif.
\end{abstract}

Kata Kunci: hakekat, pelayanan publik, barang publik, administratif, jasa

\begin{abstract}
The essence of this public service, according to Denhardt, is as follows: serving citizens not customers, prioritizing public interests, respecting citizens more than entrepreneurs, thinking strategically and acting democratically, realizing that accountability is not easy, serving rather than controlling, respecting people, not merely productivity, through the service of public goods; public services, and administrative services.
\end{abstract}

Keywords: essence, public services , public good, administrative, services

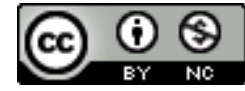

License

This work is licensed undera Creative Commons Attribution-NonCommercial 4.0 International 


\section{PENDAHULUAN}

Tujuan lahirnya negara adalah untuk mensejahterkan rakyat berhubungan dengan apa yang disebut dengan tugas mengurus dan tugas mengatur. Terkait dengan tugastugas yang diselenggarakan pemerintah dalam negara modern, N.M. Spelt dan J.B.J.M. ten Berge, membedakannya ke dalam tugas-tugas mengatur dan tugas-tugas mengurus (ordenende en verzorgende taken). Selanjutnya dapat dilihat dari pernyataan N.M. Spelt dan J.B.J.M. ten Berge, bahwa: Tugas mengurus penguasa terutama dalamsejarah masa kini telah tumbuh pesat dengan berkembang konsep negara pengurus kemasyara-katan (sociale verzorgingstaat). Demikianlah keterlibatan penguasa dalam bidang-bidang kesejahteraan sosial ekonomi dan pemeliharaan kesehatan masyarakat sangat besar. Dalam rangka tugas-tugas mengurus, penguasa bertindak aktif dengan menyediakan sarana-sarana (finansil dan personil).

Citasi ini menunjukkan, bahwa pelayanan kepada masyarakat merupakan konsekuensi logis dari kewajiban pemerintah Indonesia sebagai negara hukum modern, yaitu pemerintah memiliki kewajiban konstitusional untuk mensejahterakan masyarakat sebagai realisasi dari amanat pembukaan UUD 1945 tersebut. Tugas memajukan kesejahteraan masyarakat ini oleh Lemaire disebut sebagai tugas bestuurszorg. Untuk merealisir tugas negara tersebut, dibentuklah organ-organ pemerintahan, yang menyeleng garakan fungsi-fungsi pemerintahan negara. Organorgan pemerintahan inilah yang menjalankan fungsi-fungsi pemerintahan sebagai manisfestasi dari negara. Pada negara-negara modern tugas mengurus dan tugas mengatur merupakan kegiatan pelayanan publik yang diselenggara-kan oleh pemerintahDi Indonesia, dalam upaya memberikan kepastian bagi terseleng garanya pelayanan publik, sejak tahun 2009 (kurang lebih sudah 11 tahun) lamanya telah dibentuk dan diberlakukan Undang-Undang Nomor 25 Tahun 2009 Tentang Pelayanan Publik (selanjutnya disebut Undang-Undang Pelayanan Publik). Pembentukan UndangUndang Pelayanan Publik dilatar belakangi oleh anggapan bahwa penyelenggaraan pelayanan publik saat itu masih dihadapkan pada kondisi yang belum sesuai dengan kebutuhan dan perubahan di berbagai bidang kehidupan masyarakat.

Kondisi tersebut di atas sebagai akar persoalan, diperlukan penyesuaian perkembangan ilmu pengetahuan, maka Peran Sumber Daya Manusia sangat penting dalam mendukung inovasi yang mampubekerja secara optimal dalam mewujudkan visi, misi organisasi, karena itu kreatifitas dan inovasi tidak dapat ditundatunda lagi, tulisan ini sejikas akan membaahas seputar pelayanan publik.

\section{METODE PENELITIAN}

Penelitian ini adalah jenis penelitian library riset, yaitu penelitian perpustakaan, dengan mengkaji buku-buku yang ada dan berhubungan, kemudin disajikan secara naratif pada tulisan ini, dan menggunakan pendekatan deduktif, dan tidak menggunakan sampel dan rumus kualitiatif maupun rumus kuwantitatif, bukan pula ingin menguji hipotesis layaknya penelitian kuantitatif, atau triangulasi pada penelitian kualitatif.

\section{TEMUAN DAN PEMBAHASAN 1. Temuan}

Terkait dengan temuan tentunya dapat berupa konsep, aturan, yang menjadi bahan untuk dipergunakan di lapangan yang sesuai dengan judul yaitu hakekat pelayanan publik, berupa hakekat pelayanan public, jenis pelayanan public, pelayanan 
administratif, pelayanan jasa public dan pelayanan barang publik 


\section{Pembahasan}

\section{Hakekad Pelayanan Publik}

Pelayanan pada hakekadnya merupakan suatu kegiatan yang terkait dengan interaksi langsung antar seseorang dengan orang lain atau mesin secara fisik, dan menyediakan kepuasan pelanggan. Kamus Besar Bahasa Indonesia (KBBI) memberi pengertian, bahwa pelayanan merupakan cara atau hasil pekerjaan melayani. Sedangkan melayani adalah menyuguhi (orang dengan makanan atau minuman; menyediakan keperluan orang; mengiyakan, menerima; menggunakan (Kamus Besar Bahasa Indonesia). Istilah publik berasal dari bahasa Inggris, yaitu publikyang berarti umum, dalam pengertian yang lebih luas adalah orang banyak, amasyarakat, bahkan negara. Dalam bahasa Indonesia baku, kata publik sudah menjadi bahasa Indonesia, yangdiberi pengertian umum, orang banyak, ramai.

Dalam kaitannya dengan fungsi negara yang harus melakukan upaya mensejahterakan rakyatnya, maka pelayanan publik berarti merupakan setiap kegiatan yang dilakukan oleh pemerintah untuk memenuhi kebutuhan masyarakatnya, baik kebutuhan layanan barang, layanan jasa, maupun layanan adminisrasi. Menurut Rasyid dalam Patton, P 1998 Pelayanan publik dapat diartikan sebagai pemberian layanan (melayani) keperluan orang atau masyarakat yang mempunyai kepentingan pada organisasi itu sesuai dengan aturan pokok dan tata cara yang telah ditetapkan.

Pada hakikatnya, pemerintah adalah pelayanan kepada masyarakat. Negara atau pemerintah tidaklah diadakan untuk melayani dirinya sendiri, tetapi untuk melayani masyarakat serta menciptakan kondisi yang memungkinkan setiap anggota masyarakat mengembangkan kemampuan dan kreativitasnya demi mencapai tujuan bersama. Pada periode masa lalu, aparatur pemerintah dikenal sebagai abdi negara dan abdi masyararakat. Kata abdi biasanya digunakan dalam bahasa kerajaan, yang berarti pelayan atau melayani dalam hal ini melayani raja atau keluarga kerajaan.

Sedangkan menurut Lijan Poltak Sinambela, mengartikan pelayanan publik sebagai pemberian layanan (melayani) keperluan orang atau masyarakat yang mempunyai kepentingan pada organisasi itu sesuai dengan aturan pokok yang telah ditetapkan. Pelayanan publik adalah pemenuhan keinginan dan kebutuhan masyarakat pada penyelenggaraan negara. Negara didirikan oleh publik atau masyarakat tentu saja dengan tujuan agar dapat meningkatkan kesejahteraan masyarakat. Pada hakekatnya negara dalam hal ini melalui birokrasi haruslah dapat memenuhi kebutuhan masyarakat. Dalam hal ini bukanlah kebutuhan secara individual akan tetapi berbagai kebutuhan yang sesungguhnya diharapkan oleh masyarakat.

Berdasarkan Pasal 1 Undang-Undang Pelayanan Publik, memberikan pengertian bahwa yang dimaksud Pelayanan publik adalah kegiatan atau rangkaian kegiatan dalam rangka pemenuhan kebutuhan pelayanan sesuai dengan peraturan perundang-undangan bagi setiap warga negara dan penduduk atas barang, jasa, dan/atau pelayanan administratif yang disediakan oleh penyelenggara pelayanan publik. Sedangkan menurut Keputusan Menteri Pendayagunaan Aparatur Negara (Menpan) Nomor 63/KEP/M.PAN/7/2003, Pelayanan Publik adalah segala kegiatan pelayanan yang dilaksanakan oleh penyelenggara pelayanan publik sebagai upaya pemenuhan kebutuhan penerima pelayanan maupun pelaksanaan ketentuan peraturan perundang-undangan.

Sebagaimana telah dikemukakan dalam latar belakang masalah, bahwa Indonesia termasuk salah satu negara hukum yang 
memiliki kewajiban untuk menyelenggarakan kesejahteraan masyarakat. Untuk itu, maka negara harus memberikan pelayanan kepada masyarakat dalam memenuhi kebutuhan hidupnya, baik kebutuhan barang maupun kebutuhan jasa. Kegiatan pemerintah inilah yang selanjutnya disebut dengan istilah pelayanan publik.

Pada saat ini, pelayanan publik menjadi permasalahan yang selalu aktual untuk dibenahi secara komprehensip, karena selama ini pelayanan publik dianggap belum mampu memberikan kepuasan terhadap masya-rakat. Dalam sejarahnya pelayanan publik muncul di awal Abad XXI, yang dikenal dengan istilah "the New Publik Service"(NPS), yang dikemukakan oleh J.V. Denhardt dan R.B. Denhardt dalam Tyran, 2003, bahwa di dalam NPS mereka yang berinteraksi dengan pemerintah bukan sekedar sebagai konsumen, tetapi juga sebagai warga negara yang memiliki hak dan kewajiban. Karena itu, menurut Denhardt pemerintah dibutuhkan oleh suatu negara demokrasi agar paradigma the New Publik Service dapat berjalan dengan baik. Esensi dari pelayanan publik ini menurut Denhardt, adalah sebagai berikut:

1)melayani warga masyarakat bukan pelanggan

2)mengutamakan kepentingan publik

3)lebih menghargai warga negara ketimbang wirausahawan

4)berfikir strategis dan bertindak demokratis 5)menyadari bahwa akuntabilitas bukan merupakan yang mudah

6)melayani daripada mengendalikan

7)menghargai orang, bukan produktivitas semata.

Menurut Undang-undang Pelayanan Publik kegiatan pelayanan publik, meliputi pelayanan barang publik dan jasa publik, serta pelayanan adminis-trasi, yaitu pendidikan, pengajaran, pekerjaaan dan usaha, tempat tinggal, komunikasi dan informasi, lingkungan hidup dan kesehatan, jaminan sosial, energi, perbankan, perhubungan, sumber daya alam dan pariwisata.

Tujuan pelayanan publik pada dasarnya bertujun untuk memuaskan dan memenuhi kebutuhan sesuai dengan keinginan masyarakat pada umumnya. Untuk mencapai hal ini diperlukan kualitas pelayanan sesuai harapan dari masyarakat. Pelayanan merupakan tugas utama yang hakiki dari sosok aparatur sebagai abdi negara dan abdi masyarakat.

Pelayanan publikmerupakan segala bentuk jasa pelayanan, baik dalam bentuk barang publik maupunjasapublik yang pada prinsipnya menjadi tanggung jawab dan dilaksanakan olehInstansi Pemerintahdi Pusat, di Daerah, dan di lingkunganBadan Usaha Milik NegaraatauBadan Usaha Milik Daerah, dalam rangka upaya pemenuhan kebutuhan masyarakat maupun dalam rangka pelaksanaan ketentuan peraturan perundang-undangan.

Berdasarkan pengertian-pengertian tersebut, kegiatan pelayanan publik telah diatur pemenuhannya berdasarkan regulasi yang dibuat oleh pemerintah dengan tujuan utamanya untuk memenuhi kebutuhan dasar dan kesejahteraan masyarakat. Dengan demikian dapat disimpulkan bahwa pelayanan publik itu adalah layanan yangdiberikan oleh aparatur pemerintah pada masyarakat yang membutuhkan apakah layanan dalam bentuk barang ataupun dalam bentuk jasa, untuk itu diharapakan layanan tersebut dapat memenuhi keinginan mereka yaitu layanan yang puas, karenanya setiap person aparatur hendaknya memahami ini, terlebih dikaitkan dengan inovasi yang sudah ada regulasinya.

2.Jenis Pelayanan Publik

Di dalam Undang-Undang Pelayanan Publik, telah dientukan bahwa pelayanan 
publik dibedakan dalam beberapa jenis pelayanan. Hal ini diatur dalam Pasal 5, yaitu:

a) pelayanan barang publik;

b) pelayanan jasa publik, dan

c) pelayanan adminsitratif.

Pengertian barang publik dalam Undang-Undang Pelayanan Publik dapat dilihat dalam penjelasan Pasal 5 ayat (3) huruf a, yaitu pelayanan yang disediakan oleh instansi pemerintah dengan menggunakan Anggaran Pendapatan dan Belanja Negara dan/atau Anggaran Pendapatan dan Belanja Daerah (APBN/APBPD), dan ditujukan untuk mendukung program pelayanan publik.

Jenis pelayanan barang dan jasa, merupakan jenis pelayanan barang dan jasa publik yang pengadaannya menggunakan Anggaran Pendapatan dan Belanja Negara, seperti penyediaan obat untuk flu burung oleh Departemen Kesehatan. Pelayaran yang diselenggarakan dan dikelola oleh P.T. (Persero) PELNI untuk memperlancar perhubungan antar pulau, Penyediaan infrastruktur transportasi perkotaan yang pengadaannya menggunakan Anggaran Pendapatan dan Belanja Daerah, dan layanan lainnya.

Sedangkan yang dimaksud barang publik menurut ketentuan Pasal 5 ayat (3) butir $b$, adalah barang yang ketersediaannya merupakan hasil dari kegiatan badan usaha milik negara dan/atau badan usaha milik daerah yang mendapat pelimpahan tugas untuk menyelenggarakan pelayanan publik (publik service obligation).

Sebagai contoh penerangan listrik dari hasil pengelolaan PT (Persero) PLN; dan juga penyediaan air bersih hasil pengelolaan perusahaan daerah air minum, yang dikelola oleh perusahaan daerah air minum.

Sementara itu, yang dimaksud jasa publik menurut ketentuan Pasal 5 ayat (4) huruf a Undang-Undang Pelayanan Publik, adalah pengadaan jasa yang sebagian atau seluruh dananya bersumber dari Anggaran Pendapatan dan Belanja Negara atau Anggaran Pendapatan dan Belanja Daerah. Jenis pelayanan jasa publik ini antara lain adalah pelayanan kesehatan (rumah sakit dan puskesmas), pelayanan pendidikan (sekolah dasar, sekolah menengah pertama, sekolah menengah atas, dan perguruan tinggi), pelayanan navigasi laut (mercu suar dan lampu suar), pelayanan peradilan, pelayanan kelalulintasan (lampu lalu lintas), pelayanan keamanan (jasa kepolisian), dan pelayanan pasar.

Mengenai pelayanan jasa publik pengertiannya sebagaimana dimak sud dalam Pasal 5 ayat (4) huruf b, merupakan jasa yang dihasilkan oleh badan usaha milik negara atau badan usaha milik daerah yang mendapat pelimpahan tugas untuk menyelenggarakan pelayanan publik (publik service obligation). Sebagai contoh, antara lain jasa pelayanan transportasi angkutan udara, laut, dan darat yang dilakukan oleh PT (Persero) Garuda Indonesia, PT (Persero) Merpati Airlines, PT (Persero) Pelni, PT (Persero) KAI, dan PT (Persero) DAMRI, serta jasa penyediaan air bersih yang dilakukan oleh perusahaan daerah air minum.

\section{Pelayanan Administratif}

Pengertian pelayanan administratif dapat dipahami melalui ketentuan Pasal 5 ayat (7) huruf a, yaitu, tindakan administratif pemerintah yang merupakan bentuk pelayanan pemberian dokumen oleh pemerintah. Pelayanan administratif ini merupakan bentuk pelayanan yang menyangkut proses pelayanan yang dilakukan oleh pemerintah, yang menghasilkan berbagai bentuk dokumen resmi yang dibutuhkan oleh publik, misalnya pelayanan pengurusan status kewarganegaraan, pelayanan pengurusan sertifikat, pelayanan pengurusan Kartu 
Tanda Penduduk (KTP), pelayanan pengurusan Akta Pernikahan, pelayanan pengurusan Akte Kkelahiran, pelayanan pengurusan Akte Kematian, pelayanan pengurusan Buku Pemilik Kendaraan Bermotor (BPKB), pelayanan pengurusan Surat Izin Mengemudi (SIM), pelayanan pengurusan Izin Mendirikan Bangunan (IMB), pelayanan pengurusan Sertipikat Kepemilikan atau Penguasaan Tanah, dan sebagainya.

Di samping pelayanan yang berupa tindakan administratif yang dilakukan oleh pemerintah, juga terdapat pelayanan administratif yang dilakukan oleh swasta yang memperoleh izin dari pemerintah. Jenis pelayanan ini diatur di dalam Pasal 5 ayat (7) huruf b. Dalam pasal ini digunakan istilah tindakan administratif non pemerintah yaitu merupakan pelayanan pemberian dokumen oleh instansi swasta (non pemerintah), antara lain layanan perbankan, layanan asuransi, layanan kesehatan, layanan keamanan, layanan pengelolaan kawasan industri, layanan penyediaan pasar, layanan penyediaan tempat-tempat hiburan/rekreasi, dan layanan pengelolaan kegiatan sosial lainnya.

\section{Pelayanan Barang Publik.}

Pelayanan barang publik, adalah layanan yang menghasilkan berbagai bentuk atau jenis barang yang digunakan olehpublik, misalnya jaringan telepon, penyediaan tenaga listrik, air bersih, sarana rekreasi, jembatan penyeberangan, dan sebagainya. Pada dasarnya pelayanan publik ini merupakan perbuatan pemerintah yang diselenggarakan untuk memenuhi kebutuhan nyata masyarakat. Perbuatan nyata pemerintah sering disebut sebagai fetelijke handelingan, atau perbuatan meteriil (meterieledaad).

\section{Pelayanan Jasa Publik}

Pelayanan Jasa Publik, adalah pelayanan yang menghasilkan berbagai bentuk jasa yang dibutuhkan oleh publik, misalnya pelayanan pendidikan, pelayanan pemeliharaan kesehatan, penyelenggaraan transportasi, pos, dan lain sebagainya.

Satu hal yang harus dipahami bahwa dalam pelayanan publik selalu ada pihak pemerintah sebagai pihak yang memberi pelayanan dan pihak masyarakat yang menerima atau membutuhkan pelayanan. Pihak pemerintah diwakili oleh institusi atau instansi pemerintah, melalui orang-orang yang memiliki wewenang untuk melakukan pelayanan kepada masyarakat. Pelayanan inilah yang kemudian menimbulkan hubungan timbal balik antara pemerintah dengan masyarakat. Hal demikian adalah tepat sekali apabila hukum administrasi disebut juga sebagai hukum yang mengatur hubungan antara masyarakat dengan pemerintah secara timbal balik.

\section{PENUTUP}

\section{Simpulan}

Pada kesimpulan ini dapat disajikan berupa konsep, aturan, yang menjadi pertimbangan untuk diterapkan di lapangan yang sejalan dengan judul yaitu hakekat pelayanan publik, berupa lima perinsip dalam pelayanan public, yaitu 1) hakekat pelayanan public, 2) jenis pelayanan public, 3) pelayanan administratif, 4) pelayanan jasa public dan 5) pelayanan barang publik

\section{Rekomendasi}

Kepada seluruh pelayan public, kiranya dalam bekerja melayani public hendaknya memperhatikan aspek 1) hakekat pelayanan public, 2) jenis pelayanan public, 3) pelayanan administratif, 4) pelayanan jasa public dan 5) pelayanan barang publik. 


\section{DAFTAR PUSTAKA}

Elanor D Glor. (2003). Applaying Innovatice Proces To Imp[rov Governance and Publik Administration and Reduce Proverty, Innovation Journal: The Publik Sector Innovation Journal, Volume 12.

Hodgetts, Ricard M (2008). Teori dan Konsep Pelayanan Publik serta Implementasinya, Bandung, Mandar Maju.

Marwan, A. (2017). Membangun Gerakan Literasi. Dipetik September 7, 2019, dari http://harian.analisadaily.com/opini/news/membangun-gerakanliterasi/339316/2017/04/11

Patton, P. (1998). Pelayanan Sepenuh Hati, Terjemahan Hermers, Dalapatra, Jakarta, Pustaka.

Tyran (2003). Diffusion of Policy Innovation.Universitat St. Gallen.

Widodo Tri Utomo (2016). Inovasi sebagai keniscayaan baru dalam Ilmu dan Praktek Administrasi Publik di Indonesia, Laskar Inovasi Deputi Inovasi Administrasi Negara. Jakarta

\section{PERATURAN}

Undang-Undang Dasar Negara Republik Indonesia 1945.

Undang-Undang Nomor 25 Tahun 2009 tentang Pelayanan Publik.

Undang Nomor 23 Tahun 2014 Tentang Pemerintahan Daerah. 